\title{
Challenges faced by teachers implementing socio-scientific issues as core elements in their classroom practices
}

\author{
Ulrika Bossér ${ }^{1,}$, , Mattias Lundin 2 , Mats Lindahl ${ }^{1}$, Cedric Linder ${ }^{3}$ \\ ${ }^{1}$ Department of Chemistry and Biomedical Sciences, Linnaeus University, Kalmar, Sweden \\ 2Department of Education, Linnaeus University, Kalmar, Sweden \\ ${ }^{3}$ Department of Physics and Astronomy, Uppsala University, Uppsala, Sweden \\ For correspondence: ulrika.bosser@lnu.se
}

\begin{abstract}
:
Teachers may face considerable challenges when implementing socio-scientific issues (SSI) in their classroom practices, such as incorporating student-centred teaching practices and exploring knowledge and values in the context of socioscientific issues. This year-long study explores teachers' reflections on the process of developing their classroom practices when implementing SSI. Video-recorded discussions between two upper secondary school science teachers and an educational researcher, grounded in the teachers' reflections on their classroom practices, provided data for the analysis. The results show that during the course of the implementation the teachers enhanced their awareness of the importance of promoting students' participation and supporting their independence as learners. However, the results also suggest a conflict between the enactment of a student-centred classroom practice and the achievement of intended learning goals. In order to accept the challenge of implementing SSI in the classroom, it is suggested that it is essential for teachers to build strategies, which integrate dialogue about learning goals.
\end{abstract}

Keywords: secondary school science, scientific literacy, socio-scientific issues, curriculum implementation, student participation, teacher reflection

\section{Introduction}

An important goal of science education is to promote the development of scientific literacy that includes knowledge, reasoning skills, and critical thinking abilities vital to informed decision-making and action in our scientifically complex society. During the last decades, science curriculum revisions in several countries have emphasized this view of scientific literacy as a goal for all students (Roberts, 2007). One way to support students' development of scientific literacy is through the integration of socio-scientific issues (SSI) in science education (Zeidler, Sadler, Simmons, \& Howes, 2005). SSI have a basis in science and are considered to be of societal importance as they raise a wide range of political, economic, and ethical issues (Ratcliffe \& Grace, 2003). The integration of SSI has the potential to provide students with rich opportunities to critically examine and evaluate scientific information and to engage in debate and decision-making. Furthermore, it has the potential to assist students with developing a realistic understanding of the possibilities and limitations of science to resolve such issues (Oulton, Dillon, \& Grace, 2004).

Teachers play a critical role when a new curriculum is implemented. However, previous research has shown that there are considerable challenges for teachers in the implementation of a new science curriculum that focuses on scientific literacy for informed decision-making and action in our society (Aikenhead, 2006; Barrue \& Albe, 2013; Ratcliffe \& Millar, 2009; Sadler, 2009; van Driel, Beijaard, \& Verloop, 2001).The implementation of such curricula calls for the incorporation of student-centred classroom practices, while exploring knowledge and values in relation to SSI. Thus, a transformation 
of prevailing classroom practices whereby the teacher is typically positioned as the transmitter of established scientific knowledge is required(Sadler, 2009).This year-long study aims at providing a better understanding of the challenges associated with implementing SSI from the teachers' perspectives.

\section{SSI as a means to promote students' development of scientific literacy}

Education in which SSI are integrated is aimed at active citizenship in our rapidly changing and scientifically complex society. It emphasizes moral reasoning and personal engagement with conflicting perspectives on value-laden SSI relevant to the students' lives and to society (Sadler, 2009; Zeidler \& Keefer, 2003). It implies that students explicitly bring their own experiences and perspectives to the learning situation, thereby creating the potential to build abridge between school science and the students' life-worlds. Through the use of social interactions and argumentation, students are given opportunities to position themselves while being challenged to explore their own values and attitudes and those of others. In the process, the students gain experience with accepting ambiguity and maintaining open-mindedness, because the issues under consideration are typically complex and consist of problems with no predetermined solution (Levinson, 2006; Zeidler \& Keefer, 2003; Zeidler et al., 2005).

The integration of SSI as core elements in the classroom practice calls for exploring knowledge in the context of SSI. A point of departure is a question or concern for which an answer or decision is required, which creates a need-to-know basis for scientific knowledge in the initial stages of the learning activity, as outlined by Zeidler, Applebaum, and Sadler (2011). Exploring knowledge in the context of SSI makes room for multiple possible outcomes, which will create opportunities to emphasize the value of the students' knowledge and perspectives, and render true meaning to the students' inquiry.

Science education that hasa scientific literacy focus realized by a SSI curriculum can be regarded as transformative (Kalantzis, 2006). Students are encouraged to reflect upon and develop their own beliefs and behaviours and to develop habits of mind, such as scepticism, the evaluation of information, and inquiry processes, in order to be able to participate in public debate and decisionmaking. Students can be empowered by means of developing fruitful habits consistent with those of independent learners (Zeidler et al., 2011). Such an approach is in sharp contrast to a focus on the reproduction of facts which is still predominant in contemporary science education (Sadler, 2009). Although an education that focuses on reproduction can still provide students with opportunities to engage in inquiry and to appropriate and rework knowledge, the purpose manifests as being limited to understanding established content knowledge (Kalantzis, 2006; Sadler, 2009). On the other hand, the transformative element that underpins the scientific literacy approach described earlier, aims at promoting students' life-long learning and their ability to create and innovate. The purpose is emancipatory in terms of preparing individuals to be responsible participants in societal change. Hence, the realization of an SSI curriculum represents a fundamental shift in the way science education is conceptualized, which certainly has extensive implications for teachers' everyday classroom practices.

\section{Implementing SSI - implications for classroom practice}

In the literature, a range of features has been proposed as desirable goals when integrating SSI in classroom practice. Addressing SSI in the classroom requires teachers to incorporate student-centred classroom practices that promote the students' development of knowledge through social interactions(Saunders \& Rennie, 2013).In such an educational environment, the teacher best functions as a facilitator who designs learning activities that provide students with opportunities to actively participate in learning experiences that include, for example, engaging with processes of inquiry and 
debate, and exploring evidence-based reasoning. Furthermore, the students' negotiation of SSI in the student-centred classroom will entail multiple possible outcomes of learning activities, which cannot be fully directed or predetermined by the teacher. Therefore, continuously communicating the learning goals and maintaining a dialogue with the students about emphasis of aims and content in relation to the curriculum are required (Barrett \& Pedretti, 2006; Ratcliffe \& Grace, 2003).

Since values and ethical considerations via social interaction and discourse are also important features of socioscientific decision-making, as emphasized by Zeidler and Keefer (2003), integration of SSI requires teachers to be skilled in structuring and leading value-laden discussions, to which students bring their personal perspectives and experiences. Consequently, it is important for teachers to strive to achieve a learning environment, characterized by mutual respect, support, and openness among participants (Levinson, 2006; Sadler, 2009).

\section{Challenges for teachers when implementing SSI in the classroom}

Changes in curricula give rise to changes in classroom practices, which are often associated with demanding challenges and dilemmas for those teachers who venture into new pedagogical territory (Beijaard, Meijer, \& Verloop, 2004). More research is needed in order to enhance our understanding of teachers' challenges related to the implementation of SSI. However, previous research in connection with the implementation of new science curricula that has focused on scientific literacy has provided some insights into particular challenges. For example, in many science classrooms, the teacher is still at the centre of the class, positioned as an expert and the authorized "transmitter" of scientific knowledge(Sadler, 2009).The literature provides descriptions of how many science teachers are unfamiliar with, and lack proficiency in, student-centred teaching strategies (Aikenhead, 2006; Saunders \& Rennie, 2013). Scholars have pointed to the difficulty of transforming the prevailing social norms in classrooms, which consist of reciprocal expectations between teachers and students concerning their roles, behaviours, and responsibilities. Reform efforts associated with transforming the traditional classroom are often met with resistance from students who have become comfortable with these established norms (Zeidler et al., 2011).

In addition, efforts to reform science education in order to promote scientific literacy as a goal for all students have been restrained by science teachers prioritizing a broad coverage of science content (Aikenhead, 2006; Sadler, 2009; van Driel et al., 2001). For students to develop scientific literacy that includes knowledge, reasoning skills, and critical thinking abilities vital to informed decision-making, they have to be provided with opportunities to personally engage in moral reasoning and conflicting perspectives on science-related societal issues (Sadler, 2009; Zeidler \& Keefer, 2003).Although a number of studies have shown that a majority of science teachers endorse the notion that values and ethics play a significant role in science, they often simultaneously perceive science as coherent, objective, and value-free, a view shaped by their own undergraduate science studies (Bryce \&Gray, 2004; Witz \& Lee, 2009). Many science teachers are unfamiliar with, or do not feel comfortable with, the integration of values and ethics related to the science content they are teaching (Sadler, Amirshokoohi, Kazempour, \& Allspaw, 2006). Accordingly, many teachers feel ill-prepared to structure and lead potentially controversial discussions in their classes (Bryce \& Gray, 2004; Sadler et al., 2006). They express fear of losing control over the learning situation and the science content that their students learn (Aikenhead, 2006). They often raise concerns about using so-called "valuable classroom time" at the expense of content knowledge (Cross \& Price, 1996; Ekborg, Ottander, Silfver, \& Simon, 2013). Altogether, previous research in connection with the implementation of new science curricula focusing on scientific literacy show that there are major challenges for teachers implementing SSI in their classrooms. Still, there is a lack of detailed understanding of the origin of these challenges (Barrue \& Albe, 2013) 
Successful implementation of a new curriculum is not simply a matter of teachers understanding and responding to goals formulated by policymakers or educational researchers. For successful implementation of any new curriculum, teachers have to reconsider the beliefs and values underlying their classroom practice (Aikenhead, 2006; Lee \& Witz, 2009; van Driel et al., 2001).Current perspectives on teachers' professional development suggest that reflection in relation to the classroom context promotes teachers' development of their knowledge, values, and beliefs. Such strategies as sharing ideas through dialogue with colleagues and participating in programs for professional development that are not solely prescriptive, but offer participants the opportunity to enact changes that can be embedded into the present classroom practice for further development are suggested (Beijaard et al., 2004; Clarke \& Hollingsworth, 2002; van Driel et al., 2001). The interplay between the implementation of new ideas in the classroom and reflecting on their outcomes is essential for the process of development. Changes in classroom practices and reflecting on their outcomes, in terms of students' actions and learning, have the potential to impact teachers' knowledge and beliefs, which in turn may influence their classroom practices as an ongoing process (Clarke \& Hollingsworth, 2002; Russel \& Munby, 1991).

\section{Aims and research questions}

Most of the empirical work on the implementation of SSI has been based on short-term interventions. Although these studies stress the importance of the teachers' involvement for successful implementation, the outcomes have been measured primarily from the students' perspective, in terms of learning the science content, understanding the nature of science, and developing informal reasoning and argumentation skills. When discussing the results of these projects, it is often reported that despite a high degree of support for the participating teachers, there have been many obstacles associated with moving teachers beyond traditional modes of science instruction (Sadler, 2009).

More research is needed to enhance our understanding of the challenges teachers face with the implementation of SSI (Barrue \& Albe, 2013). There is a lack of studies where teachers develop their practices towards the integration of SSI without detailed intervention (Sadler, 2011). In particular, longitudinal studies in which SSI are integrated as core elements in the classroom practice are scarce (Zeidler, Sadler, Applebaum, \& Callahan, 2009).The present year - long research study aims at adding to our understanding of the challenges teachers may face as well as the developments that may be stimulated in response to challenges related to the development of classroom practices towards the integration of SSI without purposeful intervention. It explores two teachers' shared reflections on their classroom practices in relation to their implementation of SSI as core elements in their classroom practices. More specifically, this investigation is guided by the following research questions:

- What developments can be identified in the teachers' reflections on their classroom practices in response to challenges they face when implementing SSI?

- What challenges persist during the process of implementing SSI, as seen through the teachers' reflections?

\section{Method}

\section{Participants and educational context}

The setting of this research project was a public upper secondary school with approximately 900 students in a small Swedish city. The project was situated in the "Science Studies" course which is compulsory for all non-science bound students in the upper secondary school in Sweden, and covers aspects of sustainable development, human sexuality and relationships, individual health and lifestyle, and biotechnology and its implications. Two male science teachers who were involved in implementing SSI throughout an academic year (about 90 hours of instructional time) and their 15-16year-old students (a total of 65 students from two classes) in the "Social Science Program" 
(preparation for higher education) participated in the study. The participating teachers have three and 10 years of teaching experience, respectively. Before the start of this research project they had participated in a 15 ECTS $^{1}$ course for practicing teachers on the use of SSI in science education. The primary source of course literature was Zeidler (2003). The course included planning lesson themes in accordance with the school curriculum. The course was taught by the third author of this study, an experienced educational researcher and teacher educator, who subsequently functioned as the two participating teachers' mentor as they worked to develop their classroom practices to implement and use SSI throughout the entire "Science Studies" course. Aimed at exploring what could realistically be experienced by teachers who implement SSI in their classrooms, there was no intentional intervention in their class activities. Only on rare occasions was the mentor asked by the participating teachers to assist them with respect to scientific content for the development of learning activities.

The two teachers' participation in this research project was voluntary, and motivated by their personal interest to carry out the implementation of SSI. The curriculum for the "Science Studies" course was revised in 2011. The revised curriculum emphasizes that the students acquire the knowledge and abilities to propose alternative courses of action using relevant arguments (The Swedish National Agency for Education, 2011, p. 1). According to the participating teachers' interpretation, the implementation of SSI was in keeping with the goals of the revised school curriculum. The two teachers' students were informed about the overall purpose of the research and were also invited to participate in accordance with Swedish ethical guidelines for such studies (The Swedish Research Council, 1990). These guidelines call for informed consent on the part of all participants, and for participants to be able to withdraw from the study at any time (in this case, declining to be audio - or video-recorded). A further ethical requirement is that it should not be possible to identify any of the participants in the reporting of the study. Written approvals were obtained from all of the students and their parents. Continuous dialogue also took place between teachers and researchers concerning classroom visits and recordings.

\section{Data collection}

The participating teachers' classrooms were visited regularly (2-4 times a month) throughout an entire school year. In addition, every sixth to eighth week, for a total of six occasions, the teachers met with their mentor to share their reflections on their efforts to implement SSI and on their outcomes. Data were collected in the form of audio- and video-recordings of lessons or parts of lessons, focusing on both the teachers' and the students' actions in the classrooms, notes regarding perceived problems made by the teachers after lessons and video-recordings of the discussions between the teachers and their mentor.

The analysis was centred on the two teachers' shared reflections about the process of implementing SSI in their classrooms, which was captured in the video-recorded discussions between the teachers and their mentor. In total, 16.5 hours of video-recordings were made and subsequently transcribed verbatim. The discussions were guided by insights into the importance of experience and reflections on the outcomes of implemented ideas as the teachers developed their professional knowledge (Clarke \& Hollingsworth, 2002; Russel \& Munby, 1991). Thus, the recordings were planned so as to provide support to the teachers while developing their practices. At the same time, the discussions provided insight into the teachers' reflections on their classroom practices, as well as the challenges they faced during the implementation process.

The starting point for the discussions was the teachers' reflections on extracts of video-recordings from observed lessons along with perceived problems presented in written form recorded by the

\footnotetext{
${ }^{1}$ European Credit Transfer and Accumulation System; 1 academic year corresponds to 60 ECTS.
} 
teachers after lessons. Video-stimulated reflections are considered to stimulate productive discussions (Borko, Jacobs, Eiteljorg, \& Pittman, 2008) and to be an appropriate way to elicit teachers' perspectives and gain a picture of their professional development (Cutrim Schmid, 2011). Since it has been reported that there are often inconsistencies between teachers' expressed beliefs and their enactment of ideas in the classroom (van Driel et al., 2001), the video clips from observed lessons served the purpose of strengthening the congruity between the teachers' expressed reflections and their enacted classroom practices(Lyle, 2003).

The extracts of video-recordings were carefully selected by the mentor to cover different aspects of classroom practices, for example, when the teachers introduced a new topic, led classroom discussions, or guided student groups. Before each meeting, the teachers watched the selected video clips individually, and commented on aspects of their classroom practices in order to prepare for the discussions. During the discussions, the teachers also had many opportunities to spontaneously address any issues they considered important. The mentor functioned as a facilitator for the discussions. The content of the discussions and the major issues addressed by the mentor in the discussions are further summarized in Table 1.

Table 1. Primary content of the discussions between the teachers and their mentor

\begin{tabular}{|c|c|c|}
\hline $\begin{array}{l}\text { Aspects of the teachers' } \\
\text { practices that formed the } \\
\text { primary focus of the } \\
\text { discussions }\end{array}$ & $\begin{array}{l}\text { Educational theme } \\
\text { covered in the course }\end{array}$ & $\begin{array}{l}\text { Major issues addressed by the mentor in } \\
\text { the discussions }\end{array}$ \\
\hline $\begin{array}{l}\text { Introducing a new theme or } \\
\text { learning activity }[1,2,3] \\
\text { Completing and summing-up } \\
\text { a theme [3] } \\
\text { Guiding student groups }[3,4] \\
\text { Leading and structuring } \\
\text { classroom discussions }[3,5] \\
\text { Comparing different learning } \\
\text { activities during the entire } \\
\text { school year [6] }\end{array}$ & $\begin{array}{l}\text { Ecology [1] } \\
\text { Sustainable development } \\
{[1,2,3]} \\
\text { Genetics and gene } \\
\text { technology }[3,4,5] \\
\text { Human sexuality and } \\
\text { relationships [5] } \\
\text { Individual health and } \\
\text { lifestyle [5] } \\
\text { Summary of entire school } \\
\text { year [6] }\end{array}$ & $\begin{array}{l}\text { The significance of: } \\
\text { - explicating and communicating } \\
\text { learning goals }[1,2,6] \\
\text { - personal relevance for the students } \\
{[1,5,6]} \\
\text { - creating space for the students' } \\
\text { contributions }[1,6] \\
\text { - manifesting what counts as valid } \\
\text { knowledge in “Science Studies" } \\
\text { classes [1] } \\
\text { - making the students' knowledge } \\
\text { visible [2,4] } \\
\text { - starting teaching from the students' } \\
\text { understanding [2,4] } \\
\text { - the presence of a dilemma [2,6] } \\
\text { - promoting the students' ownership of } \\
\text { learning activities [3] } \\
\text { - emphasizing the students' } \\
\text { responsibility for their learning }[3,5] \\
\text { - recognizing the students' personal } \\
\text { perspectives [5,6] }\end{array}$ \\
\hline
\end{tabular}

The numbers in square brackets represent the number of the meeting during which the content was addressed.

\section{Data analysis}

To identify developments in the teachers' reflections and persistent challenges faced by the teachers, their reflections were interpreted in relation to the features proposed as desirable goals when 
integrating SSI in the classroom (see Table 2). The investigation was performed jointly by two researchers (the first and second author of this study) who continuously discussed and compared their interpretations. Colleagues and doctoral students at the department were also invited to compare and discuss interpretations of the teachers' utterances to reach a common understanding of the

Table 2. Summary of features proposed in the literature as desirable goals when integrating SSI in the classroom

- Students' active participation in learning activities in which they develop their knowledge through social interactions is emphasized

- Students' knowledge, personal perspectives, and experiences are recognized in the learning situation

- Knowledge is explored in the context of SSI

- Moral reasoning and exploration of conflicting perspectives are essential

- The issues under consideration are of relevance for students and are complex and value-laden, which imply multiple possible outcomes

- Learning goals are explicit and shared by teacher and students

- Aims at enhancing students' independence as learners

- The learning environment is characterized by mutual respect, support, and openness among participants

The above mentioned features are discussed in the following papers: Barrett \& Pedretti, 2006;

Levinson, 2006; Ratcliffe \& Grace, 2003; Sadler, 2009; Saunders \& Rennie, 2013; Zeidler et al., 2011;

Zeidler \& Keefer, 2003; Zeidler et al., 2005.

meaning of the teachers' reflections. After a first summary of preliminary results in terms of developments in the teachers' reflections on their classroom practices and persistent challenges faced by the teachers, it was decided to group the teachers' reflections on their teaching practices into the following categories: goals (students' actions and students' learning); design (selecting, sequencing, and organizing content, tasks, activities, and resources); and enactment (teacher behaviour) of learning activities. These aspects have previously been put forward by, for example, Ratcliffe and Grace (2003) as key pedagogical considerations for teachers when implementing new ideas in their classrooms. In order to investigate how the teachers' reflections on design and enactment of learning activities were related to the goals of these activities, the framework for teacher decision-making presented by Clough, Berg, and Olson (2009) was used. Finally, the first author re-read the transcripts to investigate the direction of causality between the teachers' reflections and the issues addressed by the mentor in the discussions in order to validate or disconfirm preliminary interpretations (Patton, 2002).

\section{Results}

In the sections below, the teachers' shared reflections during the course of SSI implementation are elicited and examples of the researchers' interpretations are provided. In as much as the teachers, in their discussions, shared reflections on the implementation of SSI, quotations are not presented as originating from one specific teacher, but are considered to originate from a common, ongoing discussion. The presentation is organized around the research questions. First, the developments identified in the teachers' reflections on their classroom practices in response to the challenges they faced are described. Second, a description of persistent challenges faced by the teachers implied by the enactment of the SSI curriculum, is provided.

Developments in the teachers' reflections on their classroom practices in response to the challenges they faced when implementing SSI 
In the teachers' discussions, developments in their reflections on their classroom practices were interpreted in terms of the teachers showing an increased awareness of the importance of classroom practices that support students' active participation in learning activities and enhance their independence as learners. The teachers' increased awareness concerned two areas of their teaching practices: first, how to encourage students to take part in classroom discussions of SSI; and second, how to develop their guiding of student groups with a view to promote the students' reasoning and judgment. Each of these two areas of development will be described in the following two sections.

Reflections regarding how to encourage students' participation in classroom discussions. The limited number of students actively participating in classroom discussions about SSI was repeatedly addressed by the teachers in relation to the goals of promoting the students' engagement in the learning activities, as well as the inclusion of students' personal perspectives and experiences into the learning situation. The teachers described this as follows: "not all of them [the students] express their views in the discussions" and it is "almost always /.../ the same [students] who speak in class." During implementation, one of the developments, as interpreted from the teachers' reflections on their classroom practices, was the variety of strategies proposed by the teachers to address this problem of limited student participation. Table 3 contains a summary of the challenges addressed by the teachers in relation to classroom discussions, as well as strategies suggested by the teachers to deal with them. Information regarding the researchers' interpretations has been added.

Table 3.Summary of challenges addressed by the teachers in relation to classroom discussions and strategies suggested by the teachers to deal with them

\begin{tabular}{|c|c|c|c|}
\hline & $\begin{array}{l}\text { Challenges addressed by } \\
\text { the teachers in relation to } \\
\text { classroom discussions }\end{array}$ & $\begin{array}{l}\text { Strategies suggested to deal } \\
\text { with the challenges }\end{array}$ & $\begin{array}{l}\text { Researchers' } \\
\text { interpretations }\end{array}$ \\
\hline $\begin{array}{l}3^{\text {rd }} \\
\text { meeting }\end{array}$ & $\begin{array}{l}\text { The limited number of } \\
\text { students taking part in } \\
\text { classroom discussions }\end{array}$ & $\begin{array}{l}\text { Design: Provide resources (e.g. } \\
\text { newspaper articles) to facilitate } \\
\text { the students personally relating } \\
\text { to the issue }\end{array}$ & $\begin{array}{l}\text { Students' preparation; The } \\
\text { possibility for students to } \\
\text { personally relate to the } \\
\text { issue under consideration }\end{array}$ \\
\hline $\begin{array}{l}4^{\text {th }} \\
\text { meeting }\end{array}$ & $\begin{array}{l}\text { The limited number of } \\
\text { students taking part in } \\
\text { classroom discussions }\end{array}$ & $\begin{array}{l}\text { Design: Select content } \\
\text { personally relevant to students } \\
\text { Design: Provide resources in } \\
\text { terms of insight into different } \\
\text { perspectives on the issue } \\
\text { Design: Urge students to write } \\
\text { down their personal } \\
\text { perspectives to make it possible } \\
\text { for the teacher to include them } \\
\text { in classroom discussions }\end{array}$ & $\begin{array}{l}\text { The possibility for students } \\
\text { to personally relate to the } \\
\text { issue under consideration } \\
\text { Students' preparation } \\
\text { Making the value of the } \\
\text { students' personal } \\
\text { perspectives visible }\end{array}$ \\
\hline $\begin{array}{l}5^{\text {th }} \\
\text { meeting }\end{array}$ & $\begin{array}{l}\text { The limited number of } \\
\text { students taking part in } \\
\text { classroom discussions } \\
\text { How to lead discussions } \\
\text { to encourage students to } \\
\text { participate in classroom } \\
\text { discussions }\end{array}$ & No strategy suggested & \\
\hline
\end{tabular}




\begin{tabular}{|c|c|c|c|}
\hline $\begin{array}{l}6^{\text {th }} \\
\text { meeting }\end{array}$ & $\begin{array}{l}\text { The risk that a strong } \\
\text { individual's opinion may } \\
\text { inhibit others to express } \\
\text { their views in classroom } \\
\text { discussions } \\
\text { How to lead discussions } \\
\text { to encourage students to } \\
\text { participate in classroom } \\
\text { discussions } \\
\text { The limited number of } \\
\text { students taking part in } \\
\text { classroom discussions }\end{array}$ & $\begin{array}{l}\text { Design: Provide time for } \\
\text { students' personal reflections } \\
\text { before carrying out classroom } \\
\text { discussions } \\
\text { Enactment: Manifest the value } \\
\text { of the students' personal } \\
\text { perspectives } \\
\text { Enactment: Manifest the value } \\
\text { of any contribution to classroom } \\
\text { discussions } \\
\text { Design: Provide the opportunity } \\
\text { for students to have small } \\
\text { group discussions before } \\
\text { carrying out a whole class } \\
\text { discussion } \\
\text { Design: Provide resources (e.g. } \\
\text { newspaper articles) to facilitate } \\
\text { the students personally relating } \\
\text { to the issue } \\
\text { Enactment: Ask questions in } \\
\text { order to facilitate the students } \\
\text { personally relating to the issue } \\
\text { Enactment: Provide examples of } \\
\text { how implications can be related } \\
\text { to the students' life-worlds to } \\
\text { facilitate the students personally } \\
\text { relating to the issue } \\
\text { Design: Provide resources in } \\
\text { terms of content knowledge }\end{array}$ & $\begin{array}{l}\text { Students' preparation; The } \\
\text { possibility for students to } \\
\text { personally relate to the } \\
\text { issue under consideration } \\
\text { The possibility for students } \\
\text { to personally relate to the } \\
\text { issue under consideration } \\
\text { The possibility for students } \\
\text { to personally relate to the } \\
\text { issue under consideration }\end{array}$ \\
\hline
\end{tabular}

The strategies focused on the design and enactment of discussions were interpreted as being related to: students' preparation; the possibility for students to personally relate to the issue under consideration; making the value of the students' personal perspectives visible; and the manifestation of the value of any contributions to the discussions. Each of these four strategies will now be further described.

First, the students' preparation for discussions about SSI in class was taken by the teachers as a way to increase the number of students who participate. The teachers suggested that they should provide background knowledge by way of, for example, lectures or newspaper articles. Additionally, they should organize for "each of them to prepare [by reflecting on the issues individually] and take notes," or by initiating discussions in small groups. This was intended to provide students with the opportunity to gain insight into a variety of perspectives on the issue under consideration and articulate a personal position, before carrying out discussions in class.

Second, the possibility for students to "personally relate to" the issue, thereby providing the opportunity to rely on their personal real-life experiences as a starting point for discussions, was suggested as a way to encourage students to participate. Alongside selecting topics for discussions of personal relevance to students, the use of scaffolding questioning was proposed to facilitate the students' personal engagement with the issue. The excerpt below concerns the teachers' reflections on a classroom discussion, in which a majority of the students did not take part. The classroom 
discussion concerned a SSI dealing with an initiative from the Swedish Minister for Health and Social Affairs, which was aimed at influencing the population to eat healthier. As a means to facilitate students personally relating to the issue, an approach involving asking challenging questions was advocated by the teachers:

It comes back to the fact that you have to be very good at understanding how to ask questions in these different situations. It might open up. / . . / How do you ask questions that get students involved? / . . . / Had they received help, like with the deduction/reasoning, like "What will happen if [the government] makes this decision/ . . . /all of a sudden you won't see this kind of food in the school cafeteria/ . . . / the student cafeteria may only sell fruit and hefty rye sandwiches, no more lollipops"/ . . ./ Then I think they had been more on the track.

Here, the teachers conclude that a teacher has to "be very good at understanding how to ask questions" in order to facilitate students' personal engagement with the issue and to "open up" for students to rely on real-life experiences as a starting point for discussions. These questions were intended to relate the implications of government policy to the students' life-worlds, for example, with the kinds of food that would be offered in the school cafeteria.

Third, the importance of making the value of students' personal perspectives visible was emphasized in the teachers' reflections. They said that a teacher should convey that all students' opinions matter by being "genuinely interested in students' responses" and to make use of them as a starting point for new reflections. To accomplish this, they suggested using remarks like: "Listen up! This was interesting, in order to further elaborate the discussion. It was also suggested that students could be urged to write down their personal perspectives on an issue in order to make it possible for the teacher to have them included in classroom discussions.

Finally, the manifestation of the value of any contributions to discussions was proposed by the teachers as a means to promote students to participate in classroom discussions. They expressed that students are "adapted to" implicit expectations about what counts as a valid contribution to a classroom discussion, possibly as a result of previous school experiences:

It could also be like trying to get them to the point where [they understand the situation as]:"Everything you say is interesting. It doesn't have to be either right or wrong."Because they're probably adapted to should you speak before the class it should be right, so to speak.

The teacher's remark that "Everything you say is interesting. It doesn't have to be either right or wrong" indicates that he anticipates the need to show the value of any contribution to discussions on SSI.

Reflections concerning guiding student groups, aimed at promoting the students' reasoning and judgment. The teachers emphasized the development of a student-centred approach to guiding student groups, with a view to supporting the students' active participation in learning activities, by promoting their reasoning and judgment. More specifically, the teachers recognized the need to give more attention to their use of guiding questions than to direct instruction as a means to encourage students to reach their own conclusions.. In the excerpt below, one of the teachers is reflecting on a SSI in which students were working in groups to design societies on small, fictitious islands in the Baltic Sea. The students had been assigned the task to propose and justify valid measures to make their societies ecologically sustainable, but they turn to the teacher for answers instead of trying to reach their own conclusions. The teacher tries to guide the students by suggesting areas for them to inquire further: 
How do you ask questions so that they become active? That's what I'm trying to do in different ways by giving examples of what they can think of without saying too much. You know it is ... The old way, so to say, I would've given a lecture, worked through: "Well, when it concerns this island, then we think like this."I'm not supposed to do that anymore.

This illustrates that the teachers are working to move from what is described as "the old way" of teaching, which involves modelling ways of reasoning through direct instruction, towards an approach aimed at facilitation, such that students "become active" as part of the process of reaching their own conclusions.

\section{Persistent challenges faced by the teachers with the implementation of SSI, as seen through their shared reflections}

From the teachers' reflections, the realization emerged that the implementation of the SSI curriculum created a number of new challenges as a result of new learning goals. The challenges reported here repeatedly appeared in all of the teachers' discussions, indicating that these challenges were not overcome during the course of the implementation. The challenges were related to two different areas: first, the new demands placed on students and teachers; and second, dealing with conflicting aims. The teachers' discussions on these challenges will be described in the two sections below.

Challenges as a result of the new demands placed on students and teachers. The new demands on teachers and students as a result of the new learning goals, implied by the realization of the SSI curriculum, brought about a number of challenges that were subsequently addressed by the teachers. The teachers addressed challenges related to: students being caught in old habits; students' resistance towards the implementation of new methods; and the meaningful unpacking of learning goals.

A recurrent element in the teachers' discussions was that "The students are caught in old habits." These habits were described as traditions concerning knowledge, learning, and assessment, firmly embedded in many of the students' notions of what science classes should be like. According to the teachers, this resulted in the students having difficulties meeting the new demands in relation to the learning goals. The teachers' reflections were concerned with how to facilitate the students to overcome these difficulties, as illustrated by the teachers' observations in the following excerpt:

... they've just been carrying on which results in they end up describing, reproducing facts, so that reflection, consideration of consequences do not occur the way I tried to guide them to when I was walking around helping them. / . . / They have to be supported in being able to consider an issue from various perspectives.

Here, the teacher describes how the students are used to reproducing content knowledge, and therefore, the teachers have to put a lot of effort into getting students to "consider an issue from different perspectives." In other words they saw students needing opportunities to practice processes of reasoning and reflect upon the consequences of different courses of action.

Students sometimes responded with questioning embedded in resistance towards new methods, aimed at negotiating dilemmas in relation to SSI and exploring different perspectives. In their discussions, the teachers expressed two different ways of dealing with students' resistance, either drawing on the curriculum for support, or deviating from their intention to implement new methods. This is illustrated in the following two excerpts. In the first excerpt, one of the teachers is reflecting on the way he drew on the curriculum to justify to students the way teaching and assessment was being carried out. 
...and why did I do it this way? And then I could point to that this is actually in the curriculum, that's why it comes off this way.

Here, the teacher justifies why he was doing it "this way" by referring back to the new curriculum. This indicates that he sees his role as an implementer of a curriculum that is governing his classroom practices.

In the second excerpt, one of the teachers is reflecting on a situation where he complied with the demands from several students who wished to be assessed by writing a test of basic content knowledge in the area of genetics, instead of an essay dealing with aspects of gene technology.

I offered a test because they retain their old ways of thinking [about learning goals]. They want study questions. They want: "Read these pages. Write this test" and that's it.

Here, students' retaining "their old ways of thinking" was given as a reason for the teacher to deviate from the full implementation of the new methods for assessment in accordance with the new learning goals.

The significance of discussing learning goals with students, in order to have them shift their focus towards the pursuit of new learning goals, was emphasized in the teachers' discussions. However, the meaningful unpacking of learning goals was addressed as a major challenge by the teachers. The excerpt below is on the teachers' reflections on the learning goals of a genetics assignment wherein the students were to identify the science content knowledge they needed in order to deal with contemporary issues in gene technology. Several students expressed confusion about the purpose of the task:

To structure knowledge, that's what you learn in this case, but I don't tell them that and I didn't think of it either. / . . . / there must be an overall . . . aim of this and I don't say that. I haven't thought of it myself. Well, I know that it is . . . I have some sort of understanding of it, but I haven't verbalized it." / . . / It makes it more complicated for them when they don't know.

From this reflection, it emerges that the teacher has not been effective in sharing his own understanding of the learning goals in connection with this specific exercise or the overall objectives of his teaching. This is taken to be an impediment to the implementation of new learning goals.

Challenges as a result of conflicting aims. The development of a classroom practice that supports the students' active participation in learning activities and enhances their independence as learners led to challenges as a result of conflicting aims. From the teachers' discussions, it emerged that enhancing the students' independence as learners meant needing to provide students with opportunities to engage in group work where they shared responsibility for acquiring the additional content knowledge they needed. However, the teachers expressed concern that, if the students governed the acquisition of knowledge on their own, it could hamper the students from reaching the learning goals. From queries such as, "For how long is it wise to let them do wrong?" the teachers emphasized their responsibility for the students' activities and learning outcomes. In this scenario, the teachers' discussions revealed a tension between the intentions to enhance the students' independence as learners and striving to control the students' activities and learning outcomes. This is illustrated in the following two excerpts. The first excerpt illustrates the teachers' intention to promote the students' reasoning. It is derived from a discussion on the task reported earlier, where the students were asked to design ecologically sustainable societies on islands in the Baltic Sea. One of the learning goals related with this task was that students should arrive at an understanding of the interconnectedness between the ecosystem and human society: 
Because the thing is that scientific solutions or problems have societal consequences, so it's like helping them to see the connection and that's not easy, but then I think that as a facilitator I have to support them in that in different ways, but in the right way so that I don't say: "This is the way it is."

Here, the teacher is saying that he has to make it possible for students to synthesize knowledge in order to reach conclusions, which is in contrast to transmitting knowledge through direct instruction, by telling students "This is the way it is."This reflects the teachers' intentions to promote the students' reasoning and judgment, which conflicts with their efforts to control the students' activities and learning outcomes, as illustrated by the second excerpt:

I'm supposed to say enough for them to understand the task, but I shouldn't tell them the answer./ . . .I want them to understand the task so that they do it the right way, the way I've imagined, so that they know what I'm after.

Thus, the teacher is saying that students should understand "what I'm after," which refers to learning outcomes, in order to carry out the task "the right way," which refers to particular activities.

The teachers' reflections revealed significant impediments to the promotion of the students' reasoning and judgment in relation to SSI including the specific difficulties to anticipate: first, the knowledge the students possess; and second, the level of scientific understanding needed by the students in order to be able to deal with a particular SSI. For example, in the area of sustainable development, one of the teachers expressed that he "has no idea" what knowledge the students bring with them in the area of sustainable development, but that he anticipated that "they don't know that much."The excerpt below, concerning students' negotiation of a SSI regarding prenatal diagnosis for the detection of Down's syndrome, provides an example of the difficulty for teachers to anticipate the knowledge needed by students in order to deal with a particular SSI:

Now there is a dilemma right from the start without them knowing anything and then I ask them what they know about genetics and then it turns out that they know a great deal. Such things I would never find out otherwise. They had a really good knowledge of genetics.

Here, the teacher had initiated the students' negotiation of an issue without prior formal instruction of predefined science content. The teacher said that he had not anticipated the sophisticated level of knowledge demonstrated by the students in the area of genetics. Concerning the quality of the classroom discussion, he expressed that the "discussion turned out ever so good." Hence, by using a SSI as a point of departure for this learning activity, the students' knowledge was revealed to the teacher.

Nevertheless, the difficulty to anticipate the knowledge needed by students, along with the reduced time devoted to covering basic science content, sometimes resulted in the teachers suggesting that the transmission of a predefined body of content to all students should be prioritized over exploring knowledge and values in the context of a SSI, as illustrated by the excerpt below:

You make sure that they have understood. During lessons they have to make sure that they understand: What is DNA? What are chromosomes? What is this and that? So you have to ... I have to provide them with this basic knowledge in this process. And then you can deal with a SSI. 
This excerpt, from the teachers' last discussion during the project, deals with their reflections on an assignment on genetics, in the context of a SSI dealing with implications of gene technology, in which the students had difficulties dealing with the content relating to the issue. The teacher expresses that he is responsible for providing the students with basic subject knowledge. Only after this knowledge has been transmitted to the students could the SSI be addressed. This could be understood as a circumstantial throwback from integrating SSI as core elements in the classroom practice towards more traditional views of teaching when dealing with topics that are perceived as requiring more profound knowledge.

\section{Discussion}

The implementation of SSI in science education entails considerable challenges for teachers, which have been reported on earlier primarily in relation to research projects focusing on students' learning outcomes (Sadler, 2009). The present longitudinal study focused on two teachers' shared reflections on their classroom practices in relation to their implementation of SSI as core elements in their classroom practices. The results provide insights into developments that can be stimulated in response to challenges related to the implementation of SSI as well as challenges that can be more persistent in relation to the establishment of a student-centred classroom in which students collaboratively explore knowledge and values in relation to SSI.

For the two teachers, the implementation of SSI provided a new starting point for teaching, in terms of presupposing that students bring their own experiences and perspectives into the learning situation and actively participate in learning activities in which they develop their knowledge through interaction. Two major challenges emerged for the teachers: first, to support students' active participation in learning activities and enhance their independence as learners while facilitating the students to reach the intended learning goals; and second, to pursue the integrated approach to use SSI as core elements in the classroom practices.

\section{Supporting students' active participation in learning activities}

Aiming at establishing a student-centred classroom, the teachers in the present study enhanced their awareness of the importance to support students' active participation in learning activities in which they develop their knowledge through interaction. The teachers paid attention to encouraging students to take part in classroom discussions on SSI and engaging students' reasoning and judgment.

The teachers noticed the limited number of students participating in classroom discussions on SSI, a crucial impediment to their implementation. The exploration of competing perspectives in relation to value-laden SSI via social interaction and discourse is an essential feature of the SSI curriculum, aimed at providing opportunities for students to critically examine and evaluate scientific information, to deal with moral reasoning, and to reflect upon and develop their personal values and beliefs (Zeidler \& Keefer, 2003; Zeidler et al., 2005). Supporting the students' active participation in learning activities by encouraging them to take part in classroom discussions emerged as an explicit target of development for the teachers in the present study. They paid considerable attention to the design and enactment of classroom discussions to promote students' active participation. Concerning design, they showed an enhanced awareness of the prerequisites for students' participation in terms of dealing with content personally relevant to students, alongside providing relevant resources and time for preparation. Apart from enhanced participation, such strategies also have the potential to develop the classroom discussions in other ways. In a previous study, Hand and Levinson (2012) showed that the same strategies are of importance for improving the quality of classroom discussions. Regarding the enactment of classroom discussions, scholars have emphasized the critical role played by the teacher as a critical questioner who encourages students to elaborate and provide justification for their standpoints, and have suggested, for example, the use of explicit frameworks to structure discussions(Hand \& Levinson, 2012; Ratcliffe \& Grace, 2003).Aiming at promoting a student-centred 
classroom, the teachers in the present study gave particular emphasis to the importance of demonstrating the value of the students' personal perspectives and the value of any contribution to discussions on SSI. This might create a problem for the teachers with respect to supporting students in reaching the intended learning goals of the course. If students are merely encouraged to share their personal points of view they will not be provided with opportunities to critically examine and evaluate scientific information, to deal with moral reasoning, and to reflect upon and develop their personal values and beliefs. Consequently, with respect to classroom discussions on SSI, the challenge for the teachers in the present study appeared to be related to designing and enacting classroom discussions so that students were encouraged to take part through expressing their views, while at the same time being expected to put forward reasons for their stance.

Furthermore, the teachers in the study emphasized the development of a student-centred approach to guiding student groups, with a view to promote students' reasoning and judgment. The teachers emphasized the use of questioning, in contrast to direct instruction, as a tool for facilitating the students' learning in terms of reaching their own conclusions. However, as previously mentioned, student inquiry into SSI in the student-centred classroom makes room for multiple outcomes of learning activities, which cannot be fully directed or predetermined by the teacher (Barrett \& Pedretti, 2006; Ratcliffe \& Grace, 2003). For the two teachers, the development of a student-centred approach to guiding student groups was associated with challenges in relation to conflicting aims in terms of enhancing the students' independence as learners while striving to control the learning situation with respect to students' activities and learning outcomes, consistent with previous findings by Ekborg et al. (2013). The aspiration to control the learning situation was associated with the fact that the two teachers expressed responsibility for ensuring that students acquire a predefined body of basic science knowledge, and questioned whether students would reach these intended learning goals by pursuing their own processes of inquiry.

Altogether, these results in relation to the enactment of classroom discussions and group projects suggest that a major challenge for the two teachers, aiming at establishing a student-centred classroom, was to support the students' active participation in learning activities and enhance their independence as learners while facilitating the students to reach intended learning goals - in this case, to be able to put forward reasoned standpoints and acquire basic science knowledge. The teachers focused their attention on strategies to encourage the students to share their points of view in classroom discussions and promote students' reasoning and judgment, activities which open up a range of possible outcomes. Thus, in order to facilitate the students reaching the intended educational goals, the learning goals associated with each learning activity need to be explicit and shared by the teacher and the students (Barrett \& Pedretti, 2006; Ratcliffe \& Grace, 2003). However, meaningful unpacking and dialogue about learning goals was described by the teachers in the present study as a significant challenge throughout the course of the implementation. This result differs from what is reported in Ratcliffe and Millar (2009) where it was observed that learning goals were communicated rather well to the students. The teachers in that project were supported by a clear course design and teaching materials (Millar, 2006) and the disparity indicates that teachers need substantive support and time for professional development to deal with the challenge of effectively communicating learning goals to students when implementing SSI.

\section{Integrating SSI as core elements in the classroom practices}

The two teachers expressed concern over the students retaining their old ways of thinking, which manifested in students focusing on the reproduction of facts and turning to the teacher for answers instead of trying to independently explore issues. Education in which SSI are integrated as core elements in the classroom practices entails exploring content knowledge and values in the context of SSI. An important point of departure for learning activities is the exploration of the students' prior knowledge, preconceptions, and perspectives in relation to the issue under consideration, as outlined 
by Zeidler et al. (2011). The teachers in the present study emphasized the inclusion of students' perspectives by encouraging students to contribute by using their personal views in classroom discussions. However, when the teachers faced the challenge of estimating the level of scientific knowledge needed by the students to be able to deal with a particular SSI, it appeared that they occasionally overlooked the importance of exploring the students' prior knowledge. Particularly when dealing with a SSI requiring more profound content knowledge, the results suggest that the teachers assumed that the students had insufficient prior knowledge to further explore the content in the context of the SSI. Based on this assumption, the teachers suggested prioritizing formal instruction of science content knowledge. Consistent with earlier findings (Ekborg et al., 2013), the teachers in the present study proposed that SSI could only be addressed after a predefined body of content had been conveyed to the students, thus returning to a more traditional view of science teaching. Therefore, the teachers might have fortified the students' conceptualizations of the reproduction of facts as the main purpose of science classes, and might also have consolidated the role of the teacher as the single source of knowledge in the classroom. Hence, teachers failing to appreciate the importance of exploring the students' prior knowledge in relation to a particular SSI might consolidate the students' difficulties to meet the new learning goals. However, the results from the present study also show that, during the course of implementation, the teachers occasionally experienced that the use of SSI as starting points for learning activities revealed the students' knowledge, making it a valuable contribution to the learning situation, which was not anticipated by the teachers. This experience suggests that integrating SSI in the classroom has the potential to bring about a development of classroom practices over time and, consequently, that teachers need to be aware of the importance of pursuing the integrated approach to using SSI as core elements in the classroom practices.

\section{Conclusion}

Students' exploration of knowledge and values in the context of SSI in a student-centered classroom implies fundamentally new relationships between teachers and students who have become used to the reproduction of established content knowledge in a teacher-centred classroom. The results from this study provide information on developments that can be stimulated by the implementation of SSI, as well as challenges teachers may face while implementing SSI as core elements in the classroom practices.

The results suggest that teachers who are interested in implementing SSI as core elements have to accept the challenge of pursuing the integrated approach to using SSI in the classroom, which calls for exploring both content knowledge and values in the context of SSI. Even the dedicated teachers in this study occasionally regressed to more traditional views of teaching, which indicates that pursuing the integrated approach might be an underestimated challenge. However, the results also suggest that integrating SSI is a beneficial way of stimulating the transformation of classroom practices in that it presupposes that students bring their knowledge and personal perspectives, allowing them to make a valuable contribution to the learning situation. The participating teachers occasionally experienced thatthe students' knowledge and personal perspectives made valuable contributions to the learning situation. They also enhanced their awareness of different strategies to support students in participating and sharing their knowledge and perspectives.

Finally, students' exploration of knowledge and values in the context of SSI in the student-centered classroom opens up a range of possible outcomes, which cannot be fully directed or predetermined by the teacher. Consequently, a dialogue about learning goals between the teacher and the students is required. Such dialogue creates opportunities to increase both the interaction between the teacher and the students, and the students' participation. The results from this study suggest that strategies to integrate dialogue about learning goals is an essential point of departure for teachers who are interested in accepting the challenge of implementing SSI as core elements in their classroom practices. Explicit learning goals shared by the teacher and the students might contribute to the 
establishment of classroom practices that enhance the students' independence as learners so that they are not primarily dependent on the teacher to pursue intended learning goals.

\section{Acknowledgements}

The authors would like to acknowledge the teachers who participated and gave their valuable time to share their reflections that made this study possible. The research was financially supported by: The Swedish Research Council VR-UVK (721-2011-5534); The Faculty of Health and Life Sciences, Linnaeus University; and The Board of Teacher Education, Linnaeus University.

\section{References}

Aikenhead, G. S., (2006). Science education for everyday life: evidence-based practice. New York: Teachers College Press.

Barrett, S. E., \&Pedretti, E., (2006). Contrasting orientations: STSE for social reconstruction or social reproduction? School Science and Mathematics, 106(5), 237-247.

Barrue, C., \&Albe, V., (2013). Citizenship education and socioscientific issues: implicit concept of citizenship in the curriculum, views of French middle school teachers. Science $\mathcal{E}$ Education, 22(5), 1089-1114.

Beijaard, D., Meijer, P.C., \& Verloop, N., (2004). Reconsidering research on teachers' professional identity. Teaching and Teacher Education, 20(2), 107-128.

Borko, H., Jacobs, J., Eiteljorg, E., \& Pittman, M. E., (2008) Video as a tool for fostering productive discussions in mathematics professional development. Teaching and Teacher Education 24(2), 417-436.

Bryce, T., \&Gray, D., (2004). Tough acts to follow: the challenges to science teachers presented by biotechnological progress. International Journal of Science Education, 26(6), 717-733.

Clarke, D., \& Hollingsworth, H., (2002). Elaborating a model of teacher professional growth.Teaching and Teacher Education, 18(8), 947-967.

Clough, M. P., Berg, C. A., \& Olson, J. K., (2009).Promoting effective science teacher education and science teaching: a framework for teacher decision-making. International Journal of Science Education, 7(4), 821-847.

Cross, R. T., \& Price, R. F., (1996).Science teachers' social conscience and the role of controversial issues in the teaching of science.Journal of Research in Science Teaching, 33(3), 319-333.

CutrimSchmid, E., (2011). Video-stimulated reflection as a professional development tool in interactive whiteboard research.ReCALL, 23(3), 252-270.

Ekborg, M., Ottander, C., Silfver, E., \& Simon, S.,(2013). Teachers' experience of working with socio-scientific issues: a large scale and in depth study. Research in Science Education 43(2), 599-617.

Hand, M., \& Levinson, R., (2012). Discussing controversial issues in the classroom.Educational Philosophy and Theory, 44(6), 614629.

Kalantzis, M., (2006).Elements of a science of education.Australian Educational Researcher, 33(2), 15-42.

Lee, H., \&Witz, K. G., (2009). Science teachers' inspiration for teaching socio-scientific issues: disconnection with reform efforts. International Journal of Science Education, 31(7), 931-960.

Levinson, R., (2006). Towards a theoretical framework for teaching controversial socio-scientific issues. International Journal of Science Education, 28(10), 1201-1224.

Lyle, J., (2003). Stimulated recall: a report on its use in naturalistic research. British Educational Research Journal, 29(6), 861-878.

Millar, R., (2006) Twenty first century science: insights from the design and Implementation of a scientific literacy approach in school science. International Journal of Science Education, 28(13), 1499-1521.

Oulton, C., Dillon, J., \& Grace, M., (2004).Reconceptualizing the teaching of controversial issues.International Journal of Science Education, 26(4), 411-423.

Patton, M. Q., (2000).Qualitative research and evaluation methods (3rded.). Thousand Oaks: Sage Publications.

Ratcliffe, M., \& Grace, M., (2003).Science education for citizenship: teaching socio-scientific issues. Maidenhead: Open University Press.

Ratcliffe, M., \& Millar, R., (2009). Teaching for understanding of science in context: evidence from the pilot trials of the twenty first century scinence courses. Journal of Research in Science Teaching, 46(8), 945-959.

Roberts, D. A., (2007).Scientific literacy/science literacy. In S. K. Abell\& N. G. Lederman (Eds.), Handbook of research on science education (pp. 729-280). Manwah: Lawrence Erlbaum Associates.

Russel, T., \&Munby, H., (1991). Reframing: the role of experience in developing teachers' professional knowledge. In D. A. Schön (Ed.), The reflective turn: case studies in and on educational practice (pp. 164-187). New York: Teachers College Press

Sadler, T. D., (2009). Situated learning in science education: socio-scientific issues as contexts for practice. Studies in Science Education, 45(1), 1-42.

Sadler, T. D., (2011). Socio-scientific issues-based education: what we know about science education in the context of SSI. In T. D. Sadler (Ed.), Socio-scientific issues in the classroom: teaching, learning and research (pp. 355-369).

Sadler, T. D., Amirshokoohi, A., Kazempour, M., \&Allspaw, K. M., (2006).Socioscience and ethics in science classrooms: teacher perspectives and strategies. Journal of Research in Science Teaching, 43(4), 353-376.

Saunders, K. J., \&Rennie, L. J., (2013). A pedagogical model for ethical inquiry into socioscientific issues in science. Research in Science Education, 43(1), 253-274. 
The Swedish National Agency for Education, (2011).̈̈mnesplaninaturkunskap[Subject syllabus for the subject science studies].Available from:

http://www.skolverket.se/polopoly_fs/1.174557!/Menu/article/attachment/Science\%20studies.pdf, (accessed 14 February 2014).

The Swedish Research Council, (1990).Forskningsetiskaprinciperinomhumanistisk-samhällsvetenskapligforskning[Ethical recommendations]. Available from:http://www.codex.vr.se/texts/HSFR.pdf, (accessed 8 December 2011).

vanDriel, J. H., Beijaard, D., \&Verloop, N., (2001). Professional development and reform in science education: the role of teachers' practical knowledge. Journal of Research in Science Teaching, 38(2), 137-158.

Witz, K., \& Lee, H., (2009). Science as an ideal: teachers' orientations to science and science education reform. Journal of Curriculum Studies, 41(3), 409-431.

Zeidler, D. L., (2003). The role of moral reasoning on socioscientific issues and discourse in science education. Doredrecht: Kluwer Academic Publishers.

Zeidler, D. L., Applebaum, S. M., \& Sadler, T. D., (2011). Enacting a socioscientific issues classroom: transformative transformations. In T. D. Sadler (Ed.), Socio-scientific issues in the classroom: teaching, learning and research (pp. 277-305). New York: Springer

Zeidler, D. L., \& Keefer, M., (2003). The role of moral reasoning and the status of socioscientific issues in science education: philosophical, psychological and pedagogical considerations. In D. L. Zeidler (Ed.), The role of moral reasoning on socioscientific issues and discourse in science education (pp. 7-33). Doredrecht: Kluwer Academic Publishers.

Zeidler, D. L., Sadler, T. D., Applebaum, S., \& Callahan, B. E., (2009). Advancing reflective judgment through socioscientific issues.Journal of Research in Science Teaching, 46(1), 74-101.

Zeidler, D. L., Sadler, T. D., Simmons, M. L., \&Howes, E. V., (2005). Beyond STS: a research-based framework for socioscientific issues education. Science Education, 89(3), 357-377. 